\title{
Yield Gap Analysis of Onion under Front Line Demonstration in Mungeli District, Chhattisgarh, India
}

\author{
Pramila Jogi* \\ Krishi Vigyan Kendra, Mungeli, Chhattisgarh, India \\ *Corresponding author
}

\section{A B S T R A C T}

\section{Keywords}

Frontline,

Demonstration,

Technology,

Production, Onion

Article Info

Accepted:

10 January 2021

Available Online:

10 February 2021
Front line demonstration on yield gap analysis in onion was conducted in Mungeli district of Chhattisgarh with participation of farmers for two years 2017-18 and 2018-19. The demonstration was conducted at 10 farmer's field according to recommended package of practices of ICAR- Directorate of onion and garlic research, Rajgurunagar. The demonstration was carried out with the objective to provide improved variety of onion (Bhima Shakti) and production technology to the farmers with the aim to reduce the cost of production and increase the yield. Use local variety is the major constraint of farmer's practices in cultivation of onion. This gap of lower production can be fulfilled by using high yielding variety of onion and adopting improved package of practices in farmer's field. The data were collected and analyzed on cost of cultivation, production, productivity; gross return and net return. Results indicated that the average maximum yield of demonstration practice was recorded $346 \mathrm{q}$ /ha yield whereas in farmers practice the yield was $236 \mathrm{q} / \mathrm{ha}$. The percent increase in yield over farmer's practices was recorded 49.47 per cent. The average technology and extension gap were computed $220.50 \mathrm{q} / \mathrm{ha}$ and $118 \mathrm{q} / \mathrm{ha}$ respectively with technology index 28.70 per cent. The demonstration gave higher average net return Rs. 923250/- And B: C ratio is 2.84. The result of the demonstration indicated the gap exists in the potential yield and improved practice yield is due to difference in soil fertility and weather condition. The result showed that yield can be increased by adopting high yielding variety and recommended package of practices.

\section{Introduction}

Onion is the most important bulb crop botanically known as Allium cepa it is a monocotyledonous plant belongs to the family Amaryllidaceae (Malik, 1994). It is consumed either raw as salad or cooked along with spices and vegetables. The flowering shoot of onion crop is known as scape which is also used as vegetable. It is rich in minerals like phosphorus and calcium and carbohydrates. It also contains protein and vitamin $\mathrm{C}$. The typical flavor of onion is due to presence of a volatile oil known as "Allyl propyl disulphide" and red colour is due to the presence of another pigment "Quercetain". A temperate crop but can be grown under a wide range of climatic conditions such as temperate, tropical and subtropical climate. Onion plant is hardy and in the young stage 
can withstand freezing temperature also. Onion is an important foreign exchange earning vegetable crop. Area the export of onion during 2011-12 was 1309863.26 thousand tonnes with a value of Rs. 1722.85 crore. Anonymous, 2011 (Indian Hort database, 2011).

In India onion is cultivated in area 1285 '000 ha with production $23262^{\prime} 000 \mathrm{mt}$. with productivity of $181 \mathrm{q} / \mathrm{ha}$ (Horticulture Statistics at a Glance 2018). In Chhattisgarh state total area under onion is 25782 ha with production 422867 metric ton and productivity 164 q/ha (Horticulture Statistics 2018-2019).

The objective of conducting this front line demonstration is to demonstrate the high yielding variety of onion with improved production technologies at farmer's field by maximum utilization of available resources including wide scale adoption and diffusion of technology at farmers' level.

\section{Materials and Methods}

The front line demonstration (FLD) is a unique approach to provide a direct interface between researcher and farmers as the scientists are directly involved in planning, execution and monitoring of the demonstrations. It is the method for transfer of technology from research to the farmer's field with the objective to maximum utilization of available resources for crop production and yield enhancement. To improve the yield of elephant foot yam with replacing local acrid variety with high yielding non acrid variety demonstration was conducted by Krishi Vigyan Kendra, Mungeli during Rabi 2017-2018 and 2018-2019 in ten farmer's field of Mungeli district. In this front line demonstration was carried out in an area of 0.4 ha adjacent to the farmers fields in which the crop was cultivated with farmers practice/ local variety.
The package of practices included in Improved practices were improved variety, seed treatement, seed rate, sowing method, recommended fertilizer dose, weed management, irrigation management, plant protection measures, etc. Improved variety of onion named Bhima Shakti was developed at DOGR, Rajgurunagar, Pune. The potential yield of this variety is $28-30 \mathrm{t} / \mathrm{ha}$. A red onion variety identified by DOGR for late kharif as well as rabi season in the states of Maharashtra, Karnataka, Andhra Pradesh, Delhi, UP, Haryana, Bihar, Punjab, Rajasthan, Gujarat, MP, Chhattisgarh and Orissa. Bulbs mature in 130 days after transplanting during late kharif and rabi season. Marketable yield during late kharif is 45.9 t/ha and during rabi $42.7 \mathrm{t} / \mathrm{ha}$. The variety has better storage for 5 6 months. Before the demonstration, farmers were trained about various technologies to be utilized during onion cultivation. Before the demonstration, farmers were trained with various technological interventions developed by Directorate of Onion and Garlic Research to be utilized in onion cultivation. All the participating farmers were guided time to time during crop production. The nursery of onion seeds were raised in first week of October month before sowing, seeds were treated with thiram @ $2 \mathrm{~g} / \mathrm{kg}$ of seed to avoid damage from damping off disease. The seedlings were transplanted in the month of December with spacing $15 \times 10 \mathrm{~cm}$ (between row to row and plant to plant). At the time of transplanting, one third of the seedling top were cut to get good establishment and the seedlings were transplanted after dipping roots in carbendazim solution $(0.1 \%)$ for two hours to reduce the incidence of fungal diseases during the establishment. The onion seedlings were transplanted after dipping roots in carbendazim solution $(0.1 \%)$ for two hours to reduce the incidence of fungal diseases during the establishment. The optimum spacing was $15 \mathrm{~cm}$ between the 
rows and $10 \mathrm{~cm}$ between plants.

All the participating farmers were guided between sowing to harvesting stage of crop. The recommended dose of fertilizer was about $110 \mathrm{~kg}$ of $\mathrm{N}, 40 \mathrm{~kg}$ of P2O5, and $60 \mathrm{~kg}$ per hectare of K2O.One third of recommended $\mathrm{N}$ and full dose of $\mathrm{P} 2 \mathrm{O} 5$ and $\mathrm{K} 2 \mathrm{O}$ were applied at the time of planting while remaining two third $\mathrm{N}$ was applied in two equal splits at 30 and 45 days after planting. In addition to NPK, sulphur is also an essential plant nutrient important for onion crop for improving yield and the pungency of onion bulbs. Soil application of $50 \mathrm{~kg} \mathrm{~S} / \mathrm{ha}$ is recommended for long day onion crops. The performance of crop was periodically observed by the scientists of Krishi Vigyan Kendra and advisory recommendations were followed. Data from FLDs and farmers practices were taken and computed to study the yield gap between front line demonstration and farmers practice results. Finally cost of cultivation, net income, cost benefit ratio was calculated. Average of cost of cultivation, yield and net return of different farmers was calculated by formula:

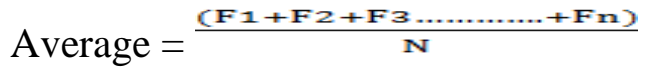

Where,

$\mathrm{F}=$ Summation of all values (n).

$\mathrm{N}=$ No. of values.

The extension gap, technology gap and technology index were calculated using formula suggested by Samui et al., (2000).

Technology Gap $=$ Pi $($ potential yield $)-D_{i}$ (Demonstration yield)

Extension Gap $=$ Di $($ Demonstration yield $)-F_{i}$ (Farmers yield)

Technology index $=\frac{\text { Potential yield }- \text { Demonstration yield }}{\text { Potential yield }} \times 100$
B: $\mathrm{C}$ ratio $=\frac{\text { Net income (Rs ha-1) }}{\text { Cost of cultivation (Rs ha-1) }}$

Percent increase over farmer's practices $=\frac{\text { Improved practices }- \text { Farmers practices }}{\text { Farmers practices }} \times 100$

\section{Results and Discussion}

The data regarding bulb yield of onion crop infront line demonstration verses farmers practice are given in Table 1. It was revealed that, the increased onion bulb yield over the farmers practice was noticed during all the years of demonstration. The maximum average onion bulbs yield (229.5 q/ha) was obtained in demonstration technology with 54 $\%$ average increased yield over the farmers practice. The results are in accordance with the results obtained by Gaharwar et al., 2018; Gupta et al., 2015; Kumar Udit, 2014 for onion crop. The yield of Onion bulb was 223 q/ha and 236 q/ha during rabi 2017-18 and 2018-19, respectively using improved practices however, in farmers practice the average yield were recorded $146 \mathrm{q} / \mathrm{ha}$ and 152 $\mathrm{q} / \mathrm{ha}$ during respective years. Increase in yield was due to high yielding variety, seed treatment with fungicide, timely sowing, recommended dose of fertilizer, proper and timely irrigation and plant protection measures. The difference in yield in different years may be due to variation in soil moisture availability, rainfall etc.

From the data presented in table 2, the average technology gap $70.50 \mathrm{q} / \mathrm{ha}$ was observed. This difference between potential yield and demonstration yield was, may be due to difference in soil fertility, management skill of individual farmers and climatic condition of the area. These findings are in accordance with Singh et al., (2011). The extension gap of 77 and $84 \mathrm{q} / \mathrm{ha}$ was recorded in onion, Bhima Shakti variety and farmer's local variety yield during 2017-18 and 201819 respectively. On an average extension gap 
in yield of two year front line demonstration was $80.5 \mathrm{q} / \mathrm{ha}$, indicating the lack in adoption of high yielding variety and use of improved production technology. By using various extension ways including block/village demonstrations in large area along with timely supply of quality inputs in technological guidance so as to minimize the technological gap in different components of onion production technology reported in this investigation. The results are in conformity with the findings of Teggelli et al., (2015).

Table.1 Yield and yield difference of elephant foot yam under front line demonstration

\begin{tabular}{|c|c|c|c|c|c|}
\hline \multirow[t]{2}{*}{ Year } & \multicolumn{3}{|c|}{ Yield (q/ha) } & \multirow{2}{*}{$\begin{array}{l}\text { Additional yield } \\
\text { over local check } \\
\text { (q/ha) }\end{array}$} & \multirow{2}{*}{$\begin{array}{c}\text { Per cent } \\
\text { increase over } \\
\text { local check }\end{array}$} \\
\hline & Potential & FLD & Farmers Practice & & \\
\hline $2017-18$ & $300 \mathrm{~g} / \mathrm{ha}$ & $223 \mathrm{q} / \mathrm{ha}$ & 146g/ha & 77 & 52.74 \\
\hline 2018-19 & $300 \mathrm{q} / \mathrm{ha}$ & $236 \mathrm{~g} / \mathrm{ha}$ & $152 \mathrm{q} / \mathrm{ha}$ & 84 & 55.26 \\
\hline Average & $300 \mathrm{q} / \mathrm{ha}$ & $229.5 \mathrm{q} / \mathrm{ha}$ & 149 q/ha & 80.5 & 54.00 \\
\hline
\end{tabular}

Table.2 Yield gap and technology index in front line demonstrations

\begin{tabular}{|c|c|c|c|c|}
\hline Year & $\begin{array}{c}\text { No. of } \\
\text { farmer }\end{array}$ & $\begin{array}{c}\text { Technology Gap } \\
(\mathbf{q} / \mathbf{h a})\end{array}$ & $\begin{array}{c}\text { Extension Gap } \\
(\mathbf{q} / \mathbf{h a})\end{array}$ & $\begin{array}{c}\text { Technology } \\
\text { Index }(\mathbf{\%})\end{array}$ \\
\hline $2017-18$ & 10 & 77 & 77 & 25.67 \\
\hline $2018-19$ & 10 & 64 & 84 & 21.33 \\
\hline Mean & - & 70.5 & 80.5 & 23.50 \\
\hline
\end{tabular}

Table.3 Economics of front line demonstrations

\begin{tabular}{|c|c|c|c|c|c|c|c|c|}
\hline \multirow{2}{*}{ Year } & \multicolumn{2}{c|}{$\begin{array}{c}\text { Cost of cultivation } \\
\text { (Rs/ha) }\end{array}$} & \multicolumn{2}{c|}{$\begin{array}{c}\text { Gross return } \\
\text { (Rs/ha) }\end{array}$} & \multicolumn{2}{c|}{$\begin{array}{c}\text { Net return } \\
\text { (Rs./ha) }\end{array}$} & \multicolumn{2}{c|}{ B:C ratio } \\
\cline { 2 - 9 } & FLD & $\begin{array}{l}\text { Farmers } \\
\text { practice }\end{array}$ & FLD & $\begin{array}{l}\text { Farmers } \\
\text { practice }\end{array}$ & FLD & $\begin{array}{l}\text { Farmers } \\
\text { practice }\end{array}$ & FLD & $\begin{array}{l}\text { Farmers } \\
\text { practice }\end{array}$ \\
\hline $2017-18$ & 62000 & 55000 & 334500 & 219000 & 272500 & 164000 & 4.39 & 2.98 \\
\hline $2018-19$ & 65000 & 57000 & 354000 & 228000 & 289000 & 171000 & 4.45 & 3.00 \\
\hline Average & 63500 & 56000 & 344250 & 223500 & 280750 & 167500 & 4.42 & 2.99 \\
\hline
\end{tabular}

The technology index reported in table 2 showed the plausibility of the demonstration technology at farmer's field. The technology index was calculated 25.67 percent and 21.33 percent during the year of demonstration. An average technology index was computed 23.50 percent. This proves the strength of new technology with recommended package of practices. As the technology index denotes the gap between technology evolved at research farm and farmers field, lower the technology index more feasible will be the technology (Jeengar et al., 2006; Hiremath and Nagraju, 2010.The economic analysis for demonstrated technology was presented in table 3 . The economics over two year between front line demonstration and farmer practice indicates that the cost of production of onion under demonstration was Rs. 62,000/- to 65,000/- ha with an average Rs.63,500/ha as well as in farmers practice cost of production was Rs. 55,000 to $57,000 /$ ha with an average Rs. 
$56,000 /$ ha. The additional cost increased in demonstration was due to more cost included in procurement of improved high yielding variety, balance dose of fertilizer and IPM practices. Bhima Shakti variety of onion is very profitable it gave higher net return of Rs. $2,72,500 /$ ha and 2, 89,000/ha on respective years with an average of Rs. 2, 80,750/ha. In farmers practices, this net return was calculated Rs.1, 64,000/ha and Rs. 1, $71,000 /$ ha in respective years $2017-18$ and 2018-19 with an average of Rs. 1, 67,500/ha. This is less as compare to demonstration. The benefit cost ratio of demonstration (FLDs) was calculated 4.39 and 4.45 with mean 4.42 whereas in farmers practice benefit cost ratio varied from 2.98 to 3.00 with mean 2.99. This is due to higher yield potential of onion variety Bhima Shakti used in demonstration and improved package of practices applied during the growth period of the crop. These findings are similar of Hiremath and Nagraju 2010; Tandel 2011.

Before demonstration at the farmer's field this variety was not very well known to the farmers and they were not aware of the improved technology for cultivation of this crop. The results of front line demonstration come out with the fact that the potential of improved production technology is beneficial for farmers.

In conclusion the front line demonstration conducted at farmers field on yield gap analysis of onion variety Bhima Shakti during successive years from 2017-18 to 2018-19 it was clear that there is wide gap between research practices and conventional cultivation practice of onion. Increased bulb yield with higher monetary returns and $\mathrm{B}$ : $\mathrm{C}$ ratio is the success of this demonstration. The front line demonstration programme was effective in changing attitude, skill and knowledge of farmers regarding recent technology emerging in different research stations. Considering the productivity and profitability the farmers expressed satisfaction with the performance of onion variety Bhima Shakti. The farmers of adjoining areas were also convinced and interested to adopt onion cultivation with this variety. The demonstration study summarized that FLDs conducted by KVK, Mungeli made significant impact on horizontal spread of this technology. The net return gained by farmers participated in this demonstration by cultivation of onion has created greater awareness and motivated other farmers to adopt demonstrated technology for production of this crop in Mungeli district. This helps to improve linkage between scientists and farmers and also enhance the tuber production, consumption, nutritional security and overall livelihood security of the farmers of Mungeli district of Chhattisgarh.

\section{References}

Bharathi C Sharmila, et al. 2015. Front line demonstration on multiplier onion (Allium cepa L. varaggregatum Don) to reduce cost of production. Journal of Krishi Vigyan. 4(1): 30-36.

Directorate of horticulture and farm forestry, 2018-19, Chhattisgarh. Horticulture Statistics.

Gaharwar M Anjali et al. 2018. Impact analysis study of front line demonstrations regarding integrated cultivation technology for onion var. Akola Safed. Journal of Pharmacognosy and Phytochemistry. 7(6): 1351-1354.

Gupta Nishithet et al. 2015. Role of front line demonstration in transfer of improved production technology of kharif onion. Research Environment Life Science. 8(3): 513-516.

Hiremath S.M. and Nagaraju M.V. 2010. Evaluation of front line demonstration trails on onion in Haveri district of Karnataka. Karnataka Journal of 
Agricultural Sciences. 22(5): $1092-$ 1093.

Hiremath S.M. and Nagaraja M.V. 2014. Yield gap analysis in onion under front line demonstration in Haveri district. International Journal of Scientific Research. 3(10): 2277-8179.

Jain Shampi and Gupta Jayant Kumar. 2018. Benefit - cost analysis of onion producer in Sagar district of Madhya Pradesh, India. International Journal of Current Microbiology and Applied Sciences. 7(1): 894-900.

Jeengar KL et al. 2006. Front line demonstration on maize in NB hilwara district of Rajasthan. Current Agric. 30:115-116.

Karabhantanal S. S et al. 2015. Impact of frontline demonstration on integrated crop management in rainfed onion. Pest management in horticultural ecosystems. 21(1): 42-45.

Kumar Udit. 2014. Weed management studies in onion (Allium cepa L.) The Asian Journal of Horticulture. 9(2):426-430.

Meena B.L., et al. 2016. Evaluation of technology dissemination through demonstration on the yield of onion, Allium cepa L. International Journal of Science, Environment and Technology. 5(3): 1711-1717.

Tandel B.M. et al. 2014. Yield and impact analysis of training and FLDs regarding scientific cultivation of Brinjal. Agriculture Update. 9(3):288-291.

Teggelli R.G. et al. 2015. Impact of Frontline demonstration on the yield and economics of Pigeonpea in Lakaburgi district of Karnataka state. International Journal of Science and Nature. 6(2): 224-227.

\section{How to cite this article:}

Pramila Jogi. 2021. Yield Gap Analysis of Onion under Front Line Demonstration in Mungeli District, Chhattisgarh, India. Int.J.Curr.Microbiol.App.Sci. 10(02): 958-963. doi: https://doi.org/10.20546/ijcmas.2021.1002.114 